Fernanda Rombini

Diego M. Cecchini

Jamile Ballivian

Mara Huberman

Analía Urueña

Isabel Cassetti

\title{
Dual therapy with raltegravir plus a fixed dose combination of darunavir/ritonavir in people living with HIV in Argentina
}

\author{
Helios Salud, Buenos Aires, Argentina
}

Article history

Received: 7 August 2020; Revision Requested: 16 September 2020; Revision Received: 21 September 2020; Accepted: 29 september 2020; Published: 3 December 2020

\section{ABSTRACT}

Objective. There are generic fixed-dose combinations (FDCs) of ritonavir-boosted darunavir (DRV/r) available in Argentina. Experiences with these FDCs in dual therapy remain limited in clinical practice. We aimed to describe clinical and virologic outcomes in patients exposed to FDC DRV/r + raltegravir (RAL) $400 \mathrm{mg}$ every $12 \mathrm{~h}$ in a real-life setting.

Patients and methods. Retrospective analysis of electronic medical records of HIV-infected patients under FDC DRV/r + RAL in an HIV clinic in Argentina (2014-2018). Individuals were classified as "switch group" (SG, undetectable viral load [VL] with any toxicity/comorbidity) and "virologic group. (VG, detectable viremia and infection by multidrug-resistant HIV).

Results. Of 7,380 patients on ART, 116 (1.5\%) received FDC DRV/r + RAL, being 58\% in SG. Sixty percent received DRV/r 800/100 mg dose (rest, 600/100 mg). The median (IQR) age and CD4+ T-cell count were: 52 (42-58) years, and 373 cell/ $\mu \mathrm{L}$ (202-642). Ninety-eight percent were ART-experienced with a median of 3 (IOR 2-5) prior treatments. Main reasons for switch (SG) were renal (57\%), cardiovascular (54\%) and bone (14\%) comorbidities. Median exposure to DRV/r + RAL was 18 months. Among patients in SG, 98\% and 96\% had undetectable VL at 6 and 12 months; in the VG, 89\% and 87\% had undetectable $V L$ at 6 and 12 months. No patient required suspension due to toxicity/ intolerance.

Conclusion. In this cohort of mostly experienced HIV-infected patients, FDC DRV/r + RAL was effective and safe. Such therapy may be considered an option for patients with comorbid conditions and/or with multidrug-resistant HIV.

Keywords: HIV infection, antiretroviral therapy, dual therapy

Correspondence:

Diego M. Cecchini

Helios Salud SA. Peru 1511/15, Buenos Aires, C1141ACG, Argentina.

Tel: +541143637400

E-mail: dcecchini@heliossalud.com.ar
Terapia dual con raltegravir mas una combinación a dosis fija de darunavir/ritonavir en personas viviendo con VIH en Argentina

\section{RESUMEN}

Objetivo. Existen combinaciones genéricas de dosis fija (FDC) de darunavir/ritonavir (DRV/r) en Argentina. Las experiencias con estas FDCs en terapia dual siguen siendo limitadas. Nuestro objetivo fue describir los resultados clínicos y virológicos en pacientes expuestos a FDC DRV/r + raltegravir (RAL) 400 mg cada12 h en la práctica clínica.

Pacientes y métodos: Análisis retrospectivo de historias clínicas electrónicas de pacientes infectados por VIH con FDC DRV/r + RAL en Argentina (2014-2018). Los individuos fueron clasificados como: "grupo de cambio" (GC, carga viral [CV] indetectable con toxicidad/comorbilidad) y "grupo virológico" (GV, viremia detectable e infección por VIH multirresistente).

Resultados. De 7.380 pacientes en tratamiento antirretroviral (TAR), $116(1.5 \%)$ recibieron FDC DRV/r + RAL, siendo 58\% GC. El 60\% recibió DRV/r 800/100 mg (resto, 600/100 mg). La mediana (IOR) de edad y de linfocitos T-CD4+ fueron: 52 (42-58) años y 373 células/ $\mu \mathrm{L}$ (202-642). El 98\% tenía experiencia en TAR con una mediana de 3 (IOR 2-5) tratamientos previos. Las razones para el cambio (GC) fueron las comorbilidades renales (57\%), cardiovasculares (54\%) y óseas (14\%). La mediana de exposición fue 18 meses. En GC, 98\% y $96 \%$ tuvieron CV indetectable a 6 y 12 meses; en GV, 89\% y $87 \%$ a 6 y 12 meses. Ningún paciente requirió suspensión debido a toxicidad o intolerancia.

Conclusión. En esta cohorte de pacientes experimentados en TAR, la FDC DRV/r + RAL fue eficaz y segura. Dicha terapia puede considerarse una opción para pacientes con comorbilidades y/o VIH multirresistente.

Palabras clave: Infección por VIH, terapia antiretroviral, terapia dual 


\section{INTRODUCTION}

Until recently, HIV treatment guidelines recommended triple antiretroviral therapy (ART) based on combining a dual nucleoside reverse transcriptase inhibitor (NRTI) backbone with a third agent, such as a ritonavir-boosted protease inhibitor (bPI), an integrase inhibitor (INSTI) or a a non-nucleoside reverse transcriptase inhibitor (NNRTI) [1-3]. However, toxicities associated with long-term use of NRTls have led to the assessment of dual therapy approaches that do not include this drug class [4]. Cohort studies describe an increased prevalence of comorbidities associated with natural aging, including renal, cardiovascular, metabolic disorders such as diabetes, dyslipidaemia and osteoporosis, among others [5-7]. These comorbid conditions appear in people living with HIV at younger ages than non-infected controls [6-8]. Drug-related adverse events associated with the long-term use of NRTIs, as other antiretrovirals, may contribute to these comorbidities [9].

Some studies have suggested a possible improvement of NRTI-related adverse events after switching to NRTI-sparing regimens. These regimens could potentially achieve and maintain viral suppression and immunologic control, reduce costs, while avoiding long term toxicities. It can also be an alternative for patients under failing regimens (eg. patients with resistance to NRTI and other drug classes) [1-4].

In Argentina, DRV/r 800/100 and 600/100 mg generic fixed-dose combinations (FDC) are available and recommended (with a NRTI backbone) for naive or experienced patients in local guidelines $[3,10]$. The FDC considerably reduces the pill burden of this bPI, allowing better tolerability. Despite this FDC showed efficacy and low prevalence of adverse events in a randomized control trial in naïve patients [11], there are no publications considering its effectiveness and safety in routine clinical practice.

Raltegravir (RAL) was the first available INSTI, approved for use in Argentina in 2008 and, until recently, the most widely used drug of this family. It leads to potent viral suppression while maintaining a favorable adverse effect profile and minimal drug interactions. Its effectiveness to rapidly control HIV viral load (VL) has been demonstrated in antiretroviral-naive and experienced patients. However, its low genetic barrier precludes its use in patients with drug resistance mutations unless associated with accompanying drugs with higher genetic barrier, such as bPIs [12-14].

Experience with DRV/r + RAL dual therapy has been limited in clinical practice with no publications considering the use of a generic FDC of DRV/r. Addressing this information will contribute to guide use of ART in certain HIV-infected populations, we aimed to describe indications, efficacy and safety of a generic FDC of DRV/r + RAL $400 \mathrm{mg}$ BID in real-life patients.

\section{PATIENTS AND METHODS}

We performed an observational retrospective cohort study carried out in a reference private center dedicated to the care of people living with HIV based in in Buenos Aires city, Argentina, with a network all over the country. The DT regimen was chosen on routine clinical practice basis by an infectious disease's specialist considering prior ART exposure, cumulative resistance profile, comorbidities, co-medications, history of adherence and tolerability to antiretrovirals, VL and CD4-T cell count.

The inclusion criteria were the following: HIV-infected patients older than 18 years, assisted in our institution network between January 2014 and December 2018, who have received DT with DRV/r + RAL for at least 24 weeks. Patients with evidence of resistance to DRV or RAL, active hepatitis B or pregnancy, or insufficient clinical and/or analytical information were excluded.

The information was obtained from the electronic medical records (Infhos ${ }^{\circledR}$ database). Data were retrospectively collected from the introduction of the DT until the last follow-up routine visit available within the study timeframe. Data collection included demographic and clinical variables (prior ART, clinical reason for indication, adverse events, virological and immunological response at 24 and 48 weeks after DT prescription). Individuals were classified as:

- Switch group (SG): suppressed patients (undetectable viral load) who switched due to toxicity or comorbidities and

- Virologic group (VG): HIV-infected patients with detectable viremia and infection by multidrug-resistant HIV (resistance to at least 2 drug classes)

Statistical analysis. For data analysis, categorical variables were described using absolute and relative frequencies and compared by $\chi 2$ test or Fisher's exact test according to expected values. Continuous variables were described using medians and interquartile ranges (IQR) and compared by t-test or Mann-Whitney test according to normality of variables. A two-sided $p$-value of $<0.05$ was considered significant.

\section{RESULTS}

Of 7,380 HIV-infected patients on ART in our institution, 236 (3.19\%) received DT and 116 received FDC DRV/ + RAL. This DT regimen was the most frequently prescribed and accounted for $1.57 \%$ of our total population. Considering demographics, $69.8 \%$ were male and the median of age was 52 years (IQR 42-59). The majority of patients were experienced in ART (98\%) with a median time of exposure of 144 months (IQR 75-228). Considering group classification, $68(58 \%)$ individuals corresponded to SG and $48(42 \%)$ to VG.

Clinical and immunovirological profile and time on dual therapy are shown in table 1. Patients in SG were older $(\mathrm{t}=$ 5.1029; $p<0.001$ ), had higher CD4 T-cell count prior to DT (t $=4.7071 ; p<0.001)$, and had been exposed longer $(t=7.8199$; $p<0.001)$ to more ART regimens $(z=8.791 ; p<0.001)$ than those in the VG. Both groups had a median of 2 prior virologic failures, with patients in $V G$ with additional ongoing failure at DT indication. Regarding prior ART: $88.8 \%$ of the patients were re- 


\begin{tabular}{|c|c|c|c|c|c|}
\hline Table 1 & \multicolumn{5}{|c|}{$\begin{array}{l}\text { Demographic and immunovirological profile of } 116 \text { HIV-infected patients under dual } \\
\text { therapy (DT) with a generic fixed dose combination of DRV/r + RAL in Argentina } \\
\text { (2014-2018). Values are number (percentages) unless otherwise stated. Switch and } \\
\text { virologic groups are compared. }\end{array}$} \\
\hline \multirow[t]{2}{*}{ Variable } & & Overall & Switch group $n=68$ & Virologic group & $p$-value \\
\hline & & $N=116$ & & $n=48$ & \\
\hline \multicolumn{2}{|c|}{ Age in years, median (IOR) } & $52(42-58)$ & $54.5(49-60)$ & $43(32.5-52.5)$ & $<0.001$ \\
\hline \multicolumn{6}{|l|}{ Gender } \\
\hline \multicolumn{2}{|l|}{ Female } & $35(30.2 \%)$ & $18(26 \%)$ & $17(35 \%)$ & 0.30 \\
\hline \multicolumn{2}{|l|}{ Male } & $81(69.8 \%)$ & $50(74 \%)$ & $31(65 \%)$ & \\
\hline \multicolumn{6}{|l|}{ CDC category } \\
\hline \multicolumn{2}{|l|}{ A } & $19(16.4 \%)$ & $12(18 \%)$ & $7(15 \%)$ & 0.30 \\
\hline \multicolumn{2}{|l|}{ B } & $44(37.9 \%)$ & $29(43 \%)$ & $15(31 \%)$ & \\
\hline \multicolumn{2}{|l|}{ C } & $53(45.7 \%)$ & $27(40 \%)$ & $26(54 \%)$ & \\
\hline \multicolumn{2}{|c|}{ Months in ART pre-DT, median (IOR) } & $144(75-228)$ & $180(108-240)$ & $120(36-180)$ & $<0.001$ \\
\hline \multicolumn{2}{|c|}{ Number of ART regimens, median (IOR) } & $3(2-5)$ & $4(3-6)$ & $2.5(1-4)$ & $<0.001$ \\
\hline \multicolumn{2}{|c|}{ Months with viral load $\leq 50$ copies $/ \mathrm{mL}$ before DT, median (IOR) } & $11(0-60)$ & $48(23-108)$ & 0 & $<0.001$ \\
\hline \multicolumn{2}{|c|}{ Number of previous virologic failures, median (IOR) } & $2(1-3)$ & $2(1-3)$ & $2(1-3)$ & 0.047 \\
\hline \multicolumn{2}{|c|}{ Cd4+ (cell/uL) count before DT, median (IOR) } & $343(196-646)$ & $454(338-772)$ & $210(106-407)$ & $<0.001$ \\
\hline \multicolumn{6}{|c|}{ Viral load (copies/mL) pre DT } \\
\hline \multicolumn{2}{|l|}{$<50$} & $64(55.2 \%)$ & $64(94 \%)$ & $0(0 \%)$ & $<0.001$ \\
\hline \multicolumn{2}{|l|}{$50-200$} & $4(3.4 \%)$ & $2(3 \%)$ & $2(4 \%)$ & \\
\hline \multicolumn{2}{|l|}{$>200$} & $48(41.4 \%)$ & $2(3 \%)$ & $46(96 \%)$ & \\
\hline \multicolumn{2}{|c|}{ Time in DT, months, median (IOR) } & $17(10-25)$ & $18.5(9-25.5)$ & $15.5(10-24)$ & 0.718 \\
\hline
\end{tabular}

ceiving triple therapy, being the most frequent the association of 2 INTI + bPi or NNRTI (detail shown in table 2).

Main reasons for prescription of DT in SG were renal (57\%), cardiovascular (54\%) and bone (14\%) comorbidities, while in the $V G$ the indication was exclusively as rescue therapy in the context of infection by multidrug resistant HIV. Regarding dosage used, 69 (59\%) and $18(37,5 \%)$ received FDC DRV/r 800/100

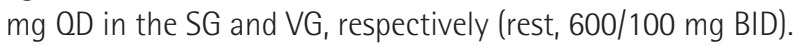

High prevalence of virologic suppression was observed at 24 and 48 weeks in both groups (table 3 ), with a trend to higher rates in SG. In 6 cases ( 4 from de VG and 2 from the SG) with $\mathrm{VL}>200 \mathrm{c} / \mathrm{ml}$ at 48 weeks, a resistance test was performed, showing emerging resistance to RAL (N155 pathway) in one patient from the VG. No patient developed resistance to DRV/r. No discontinuations of DT due to adverse events (toxicity or intolerance) were observed. Considering mortality, one individual $(1.47 \%)$ in the SG group died of non-HIV related cause (septic shock in a diabetic patient with chronic renal disease).

\section{DISCUSSION}

Effective ART is the most important intervention in terms of improving quality of life and survival in HIV-infected popu- lation. This therapy should involve combinations of drugs recommended by current guidelines, mostly based on two NRTIS plus a third drug, which may vary according to regional policies: INSTI, NNRTI, or a bPI [1-3]. Despite current drugs are safe and with minimal tolerance issues, certain proportion of patients may require an individualized approach due to either comorbidities or resistance that precludes the use of NRTIs and other drug classes $[4,9,15]$.

As far as we know, in this study we provide the largest experience in DT based in the use of DRV/r + RAL in a real-life setting using exclusively a generic FDC of the bPI. Our population represents ART-experienced patients in two complex clinical scenarios: those with comorbidities that required a NRTI-sparing regimen to prevent/minimize mainly renal and cardiovascular adverse events, and patients with limited therapeutic options due to multidrug-resistant HIV. Despite other INSTIs (elvitegravir, dolutegravir) were approved for use in Argentina during the period of the study, access was limited until recently and no experience in dual therapy in clinical practice could be documented. Of, note elvitegravir (with cobicistat booster) is only available as triple drug combination and not as independent medication. Bictegravir was approved in 2019 in Argentina and is available only as part of a coformulation with tenofovir alanfenamide and emtricitabine. 


\begin{tabular}{|c|c|c|}
\hline Table 2 & \multicolumn{2}{|c|}{$\begin{array}{l}\text { Prior ART exposure (last regimen) in } \\
\text { patients with prescription of a fixed dose } \\
\text { combination of DRV/r + RAL in Argentina }\end{array}$} \\
\hline \multirow{2}{*}{\multicolumn{2}{|c|}{ ARV family prior to DT }} & $\%$ subjects \\
\hline & & $N=116$ \\
\hline \multicolumn{2}{|l|}{2 NRTIs } & $1(1.0 \%)$ \\
\hline \multicolumn{2}{|l|}{3 NRTls } & $1(1.0 \%)$ \\
\hline \multicolumn{2}{|c|}{3 NRTIs + NNRTI } & $1(1.0 \%)$ \\
\hline \multicolumn{2}{|c|}{4 NRTIs + NNRTI } & $1(1.0 \%)$ \\
\hline \multicolumn{2}{|c|}{2 NRTIs + ANTCCR5 } & $1(1.0 \%)$ \\
\hline \multicolumn{2}{|c|}{ NRTI +ANTCCR5 + bPI + INSTI } & $1(1.0 \%)$ \\
\hline \multicolumn{2}{|c|}{2 NRTIs + bPI + ANTICCR5 } & $1(1.0 \%)$ \\
\hline \multicolumn{2}{|c|}{ NNRTI + bPI + INSTI } & $1(1.0 \%)$ \\
\hline \multicolumn{2}{|c|}{$N R T I+N N R T I+b P I$} & $1(1.0 \%)$ \\
\hline \multicolumn{2}{|c|}{2 NRTIS + INSTI } & $2(1.9 \%)$ \\
\hline \multicolumn{2}{|l|}{ NNRTI + bPI } & $2(1.9 \%)$ \\
\hline \multicolumn{2}{|c|}{$N R T I+b P I+I N S T I$} & $2(1.9 \%)$ \\
\hline \multicolumn{2}{|c|}{$2 \mathrm{NRTIS}+\mathrm{NNRTI}+\mathrm{bPI}$} & $3(2.9 \%)$ \\
\hline \multicolumn{2}{|c|}{ ANTCCR5 + bPI } & $3(2.9 \%)$ \\
\hline \multicolumn{2}{|l|}{$3 \mathrm{NRTI}+\mathrm{bPI}$} & $9(8.7 \%)$ \\
\hline \multicolumn{2}{|l|}{ bPI + INSTI } & $10(9.6 \%)$ \\
\hline \multicolumn{2}{|l|}{2 NRTIs + bPI } & $29(27.9 \%)$ \\
\hline \multicolumn{2}{|c|}{2 NRTIs + NNRTI } & $35(33.7 \%)$ \\
\hline
\end{tabular}

DT: dual therapy; NRTI: nucleoside reverse transcriptase inhibitor; NNRTI: nonnucloside reverse transcriptase inhibitor; bPI: ritonavir boosted protease inhibitor; INSTI: integrase strand transfer inhibitor; ANTCCR5: CCR5 antagonist.

patients in SG had also history of virologic failure that didn't impact sustaining virologic suppression with this DT strategy. Prevalence of adverse events and tolerance issues leading to discontinuation of this two-drug combination was null, providing empirical evidence of the safety of this strategy in complex populations.

Our results are consistent with other studies concerning the efficacy and tolerability of DRV/r + RAL in treatment-experienced patients. Maddeadu et al, described an overall 9\% probability of virologic failure at 24 months in experienced patients switched to RAL + DRV/r in the ICONA Foundation Study [16]. Jablonowska et al, in a cohort of 109 experienced patients described no discontinuations of this DT due to virologic failure, and low rates of adverse events, being simplification strategies the main reason for stopping this regimen $[17,18]$. Nishijima et al, on behalf of the SPARE study team, described 100\% suppression rates at week 48 in patients switched to this DT due to prevention of TDF renal toxicity [19].

Despite our study has limitations inherent to its retrospective and descriptive nature that may limit the generalization of the results, our cohort provides evidence of the efficacy and safety of a generic FDC of DRV/r + RAL in a pretreated population, supporting this DT as an option for selected individuals with comorbid conditions or drug resistance.

\section{ACKNOWLEDGEMENTS}

Data in this paper were presented in part at the 17th European AIDS Conference (EACS 2019) November 6-9, 2019, Basel, Switzerland (abstract PE 2/27).

The authors would like to thank Clau-

\begin{tabular}{l|l}
\hline Table 3 & $\begin{array}{l}\text { Virologic outcomes at } 24 \text { and } 48 \text { weeks in HIV-infected } \\
\text { patients under dual therapy with a generic fixed dose } \\
\text { combination of DRV/r + RAL in Argentina (2014-2018). } \\
\text { Switch and virologic groups are compared }\end{array}$
\end{tabular}

\begin{tabular}{lcccc}
\hline Variable & Overall & Switch group & Virologic group & p-value \\
\hline $\begin{array}{l}\text { Viral load at 24 weeks }(n=116) \\
\quad 50\end{array}$ & $110(94.8 \%)$ & $67(99 \%)$ & $43(90 \%)$ & 0.08 \\
$\quad 6200$ & $6(5.2 \%)$ & $1(1 \%)$ & $5(10 \%)$ & \\
Viral load at 48 weeks $(n=112)$ & & & & \\
$<50$ & $103(91.96 \%)$ & $63(97 \%)$ & $40(85 \%)$ & 0.054 \\
$50-200$ & $2(1.79 \%)$ & $0(0 \%)$ & $2(4 \%)$ & \\
$>200$ & $7(6.25 \%)$ & $2(3 \%)$ & $5(11 \%)$ & \\
\hline
\end{tabular}
dia Vecchio MD, for her contribution to this project.

\section{FUNDING}

None to declare.

\section{CONFLICT OF INTERESTS}

The authors declare that they have no conflict of interest.

\section{REFERENCES}

Considering efficacy, overall high rates of virologic suppression were observed in both groups, with a trend to higher suppression rates in the SG at 48 weeks. This difference may be potentially attributable to more frequency of adherence issues, higher burden of drug resistance in the $V G$, and to the fact that no patient in this group had virologic suppression prior to DT initiation. Of note, in addition to comorbid conditions,
1. Panel on Antiretroviral Guidelines for Adults and Adolescents. Guidelines for the Use of Antiretroviral Agents in Adults and Adolescents with HIV. Department of Health and Human Services. Available at http://www.aidsinfo.nih.gov/ContentFiles/AdultandAdolescentGL.pdf. Accessed 25 June 2020.

2. E.A.C.S. European Guidelines for the treatment of people living with HIV (PLWH) in Europe. Guidelines. 2019. Available at https:// 
www.eacsociety.org/guidelines/eacs-guidelines/eacs-guidelines. Accessed 25 June 2020.

3. Sociedad Argentina de Infectología. VII Consenso Argentino de Terapia Antirretroviral. Available at https://www.sadi.org.ar/ guias-recomendaciones-y-consensos/item/771-vii-consenso-argentino-de-terapia-antirretroviral-2018-2019. Accessed 25 June 2020.

4. Soriano V, Fernandez-Montero JV, Benitez-Gutierrez L, Mendoza $C$ d., Arias A, Barreiro P, et al. Dual antiretroviral therapy for HIV infection. Expert Opin Drug Saf. 2017;16(8):923-32. doi: 10.1080/14740338.2017.1343300

5. Guaraldi G, Milic J, Mussini C. Aging with HIV. Curr HIV/AIDS Rep. 2019;16(6):475-81. doi: 10.1007/s11904-019-00464-3.

6. Christensen S, Wolf E, Altevers J, Diaz-Cuervo H. Comorbidities and costs in HIV patients: A retrospective claims database analysis in Germany. PLoS One. 2019;14(11):1-11. doi: 10.1371/journal. pone. 0224279

7. Smith CJ, Ryom L, Weber R, Morlat P, Pradier C, Reiss $P$, et al. Trends in underlying causes of death in people with HIV from 1999 to 2011 (D:A:D): A multicohort collaboration. Lancet. 2014;384(9939):241-8. doi: 10.1016/S0140-6736(14)60604-8.

8. Schouten J, Wit FW, Stolte IG, Kootstra NA, Van Der Valk M, Geerlings $\mathrm{SE}_{1}$ et al. Cross-sectional comparison of the prevalence of age-associated comorbidities and their risk factors between hiv-infected and uninfected individuals: The age H IV cohort study. Clin Infect Dis. 2014;59(12):1787-97. doi: 10.1093/cid/ciu701.

9. Margolis AM, Heverling $H$, Pham PA, Stolbach A. A Review of the Toxicity of HIV Medications. J Med Toxicol. 2014;10(1):26-39. doi: 10.1007/s13181-013-0325-8.

10. República Argentina Poder Ejecutivo Nacional. Disposición D-2019-2880-APN-ANMAT\#MSYDS. Available at http://www.anmat.gov.ar/boletin_anmat/marzo_2019/Dispo_MSYDS_2880-19. pdf. Accessed 25 June 2020.

11. Figueroa MI, Sued OG, Gun AM, Belloso WH, Cecchini DM, Lopardo G. DRV/R plus 3TC for HIV-1 treatment naïve patients: week 48 results of the ANDES study. Presented at: 2018 Conference on Retroviruses and Opportunistic Infections (CROI); March 4-7, 2018. Boston, MA, USA

12. Mesplède $T$, Wainberg MA. Resistance against integrase strand transfer inhibitors and relevance to HIV persistence. Viruses. 2015; 7(7):3703-18. doi: 10.3390/v7072790.

13. de Miguel $R$, Montejano $R$, Stella-Ascariz N, Arribas JR. A safety evaluation of raltegravir for the treatment of HIV. Expert Opin Drug Saf. 2018;17(2):217-23. doi: 10.1080/14740338.2018.1411903.

14. Quashie PK, Mesplède T, Wainberg MA. HIV drug resistance and the advent of integrase inhibitors. Current Infectious Disease Reports. 2013; 15(1):85-100. doi: 10.1007/s1 1908-012-0305-1.

15. Baril JG, Angel JB, John Gill M, Gathe J, Cahn P, Van Wyk J, et al. Dual therapy treatment strategies for the management of patients infected with HIV: A systematic review of current evidence in ARV-naive or ARV-experienced, virologically suppressed patients. PLoS One. 2016;11(2):1-32. doi: 10.1371/journal.pone.0148231.eCollection 2016.

16. Madeddu G, Rusconi S, Cozzi-Lepri A, Di Giambenedetto S, Bonora
S, Carbone A, et al. Efficacy and tolerability of switching to a dual therapy with darunavir/ritonavir plus raltegravir in HIV-infected patients with HIV-1 RNA $\leq 50$ cp/mL. Infection. 2017;45(4):521-8. doi: 10.1007/s15010-017-1018-z.

17. Jabłonowska E, Pulik P, Kalinowska A, Gąsiorowski J, Parczewski $M$, Bociąga-Jasik $M$, et al. Efficacy and safety of nucleoside-sparing regimen based on raltegravir and ritonavir-boosted darunavir in HIV-1-infected treatment-experienced patients. J Med Virol. 2017;89(12):2122-9. doi: 10.1002/jmv.24826.

18. Jabłonowska E, Pulik P, Kalinowska A, Gąsiorowski J, Parczewski $M$, Bociąga-Jasik $M$, et al. Dual therapy based on raltegravir and boosted protease inhibitors - the experience of Polish centers. Arch Med Sci. 2018;14(4):860-4. doi: 10.5114/aoms.2016.62445.

19. Nishijima $T$, Gatanaga $H$, Shimbo $T$, Komatsu $H$, Endo $T$, Horiba $M$, et al. Switching Tenofovir/Emtricitabine plus Lopinavir/r to Raltegravir plus Darunavir/r in Patients with Suppressed Viral Load Did Not Result in Improvement of Renal Function but Could Sustain Viral Suppression: A Randomized Multicenter Trial. PLoS One. 2013;8(8):1-10. doi: 10.1371/journal.pone.0073639. 